\title{
STRATEGI PEMBELAJARAN FIQIH THAHARAH DI SDN MUNDAR KECAMATAN LAMPIHONG KABUPATEN BALANGAN
}

\author{
Oleh: \\ Hikmatu Ruwaida \\ Dosen, Sekolah Tinggi Ilmu Al-Qur' an (STIQ) Amuntai, \\ Kalimantan Selatan \\ Ruwaida0212@gmail.com
}

\begin{abstract}
Abstrak
Lemahnya proses pembelajaran merupakan salah satu problem dalam dunia pendidikan di Indonesia saat ini. Dalam proses pembelajaran, anak kurang didorong untuk mengembangkan kemampuan berpikir, mereka cenderung diarahkan untuk menghafal informasi sehingga murid lebih kepada pintar secara teoritis tetapi lemah dalam aplikasi. Melihat realitas inilah perlunya perubahan dalam proses pembelajaran dalam dunia pendidikan saat ini. Maka dikembangkan pula berbagai strategi-strategi baru yang berguna untuk menunjang tercapainya Standar Kompetensi Lulusan (SKL) yang dikehendaki menurut standar yang telah ditetapkan Di SD, walaupun kajian materi thaharah tidak terlalu dalam, diharapkan guru mampu memberikan pengajaran yang maksimal sebab Islam memberikan perhatian yang lebih terhadap kebersihan seseorang sampaisampai bersih merupakan kunci sahnya pelaksanaan ibadah. Dalam penelitian ini akan diungkapkan bagaimana strategi guru mengajarkan fiqih thaharah pada anak SD. Penelitian ini menggunakan penelitian kualitatif. Teknik pengumpulan data menggunakan wawancara, observasi dan dokumentasi. Analisis data terdiri dari reduksi data, penyajian data dan penarikan kesimpulan. Adapun hasi penelitian menujukkan bahwa Guru PAI di SDN Mundar menggunakan strategi pembelajaran ekspositori dan inkuiri dalam mengajarkan fiqih thaharah kepada peserta didik. Guru melaksanakan strategi pembelajaran dengan beberapa langkah. Secara umum, langkah-langkah dalam pelaksanaan penerapan
\end{abstract}

Al-Madrasah: Jurnal Ilmiah Pendidikan Madrasah Ibtidaiyah Vol. 3, No. 2, Januari-Juni 2019 
Hikmatu Ruwaida: Strategi Pembelajaran Fiqih Thaharah di SDN Mundar Kecamatan Lampihong Kabupaten Balangan

strategi pembelajaran yaitu guru memberikan materi secara ringkas, guru meminta peserta didik untuk mengikuti langkah-langkah strategi pembelajaran, guru bersama peserta didik melakukan klarifikasi, kesimpulan dan tindak lanjut berupa evaluasi pembelajaran.

Kata Kunci : Strategi Pembelajaran, Fiqih Thaharah

\section{A. Pendahuluan}

Pendidikan dalam Undang-Undang Sistem Pendidikan Nasional Nomor 20 Tahun 2003 adalah "usaha sadar dan terencana untuk mewujudkan suasana belajar dan proses pembelajaran agar peserta didik secara aktif mengembangkan potensi dirinya untuk memiliki kekuatan spiritual keagamaan, pengendalian diri, kepribadian, akhlak mulia, serta ketrampilan yang diperlukan dirinya, masyarakat, bangsa dan negara". ${ }^{1}$

Pendidikan merupakan proses mengubah tingkah laku anak didik melalui proses belajar. Pendidikan adalah menyiapkan untuk terjun ke dalam kehidupan yang nyata. Oleh karena itu pendidikan merupakan sebuah proses pembentukan fisik dan mental, merupakan proses budaya untuk membentuk sebuah karakter guna meningkatkan harkat dan martabat manusia melalui belajar. Belajar pun tentunya bukan merupakan proses tanpa tujuan. Seluruh kegiatan belajar akan diarahkan untuk mencapai tujuan pendidikan.

Belajar merupakan aktivitas interaksi aktif individu terhadap lingkungan sehingga terjadi perubahan tingkah laku. Sementara pembelajaran adalah penyediaan kondisi yang mengakibatkan terjadinya proses belajar pada diri peserta didik. ${ }^{2}$ Penciptaan kondisi belajar dapat dilakukan dari peserta didik sendiri atau dari guru sebagai bentuk bantuan belajar. Bantuan belajar ini berfungsi untuk mengembangkan potensi yang ada pada peserta didik sendiri. Cet. Ke-4, h. 3.

${ }^{1}$ Syaiful Sagala, Konsep dan Makna Pembelajaran, (Bandung: Alfabeta, 2006),

${ }^{2}$ Ridwan Abdullah Sani, Inovasi Pembelajaran, (Jakarta: Bumi Aksara, 2014), h. 40 . 
Hikmatu Ruwaida: Strategi Pembelajaran Fiqih Thaharah di SDN Mundar Kecamatan Lampihong Kabupaten Balangan

Oleh sebab itu, guru sangat berperan penting dalam menciptakan lingkungan yang kondusif melalui interaksinya dengan peserta didik dan sumber belajar.

Dalam Undang-Undang Sistem Pendidikan Nasional No. 20 Tahun 2003 juga disebutkan bahwa:

Pendidikan nasional berfungsi mengembangkan kemampuan dan membentuk watak serta peradaban bangsa yang bermartabat dalam rangka mencerdaskan kehidupan bangsa, bertujuan untuk berkembangnya potensi peserta didik agar menjadi manusia yang beriman dan bertakwa kepada Tuhan Yang Maha Esa, berakhlak mulia, sehat, berilmu, cakap, kreatif, mandiri, dan menjadi warga negara yang demokratis serta bertanggung jawab. ${ }^{3}$

Pembentukan watak serta peradaban bangsa yang bermartabat adalah salah satu esensi utama dari ajaran agama, dan pendidikan agama sebagai salah satu media yang sangat strategis untuk pembudayaan karakter bangsa. Dengan merujuk kepada tingginya peran agama bagi arah kehidupan bangsa Indonesia, maka pendidikan agama, khususnya Pendidikan Agama Islam di sekolah harus dilaksanakan semaksimal mungkin. Pada tataran inilah Pendidikan Agama Islam harus mampu membentuk karakter anak bangsa dan anak harus mampu mentransfer nilai-nilai ajaran agama dalam kehidupan sehari-hari.

Materi pembelajaran tidak bisa hanya sekedar hafalan dan pemahaman, guru harus bisa membawa anak kepada tingkat kemampuan yang lebih tinggi. Lebih lanjut lagi bahwa dalam karakteristik kurikulum 2013 yang salah satunya dijelaskan bahwa sekolah merupakan bagian dari masyarakat yang memberikan pengalaman belajar terencana dimana peserta didik menerapkan apa yang dipelajari di sekolah ke masyarakat dan memanfaatkan masyarakat sebagai sumber belajar.

${ }^{3}$ Undang-undang Republik Indonesia Nomor 20 Tahun 2003 Tentang SISDIKNAS dan Peraturan Pemerintah Republik Indonesia Tahun 2010 Tentang Penyelenggaraan Pendidikan Serta Wajib Belajar (Bandung: Citra Umbara, 2010), Cet. Ke- 1, h. 6. 
Hikmatu Ruwaida: Strategi Pembelajaran Fiqih Thaharah di SDN Mundar Kecamatan Lampihong Kabupaten Balangan

Advanced American Dictionary menyebutkan bahwa pembelajaran sebagai "knowledge gainet through reading and study, small changes in behavior that result from experience or training". ${ }^{4}$ Jadi, dari pembelajaran akan terjadi perubahan tingkah laku sebagai hasil dari proses latihan guna mencapai tujuan yang telah ditetapkan dan guru bukan lagi sebagai sumber belajar tetapi akan berfungsi sebagai fasilitator.

Pengetahuan yang didapat anak harus diperoleh melalui beberapa proses. Sama halnya dengan pembelajaran pendidikan agama Islam, peserta didik hendaknya diarahkan untuk mengeksplorasi pengetahuan agama dengan latihan, baik itu melalui pengalaman dan pengamalan langsung, menemukan masalah, memberi contoh dan sebagainya.

Pembelajaran pendidikan agama di sekolah tidak bisa hanya dilakukan dalam tataran teori semata tanpa bisa dimaknai oleh peserta didik. Oleh karena itu, guru memiliki kreativitas dan inovasi dalam mengantisipasi berbagai tantangan tersebut. Pembelajaran pendidikan agama hendaknya mampu memotivasi anak didik mengembangkan cara berpikir logis, sistematis dan kritis. Pembelajaran itu dengan didasarkan pada ayat-ayat Alquran yang mengajak manusia untuk menggunakan akalnya dalam memahami semua ciptaan Allah, melakukan observasi, dan lain sebagainya yang mampu mendorong anak didik untuk melatih dan mengasah akalnya.

Lemahnya proses pembelajaran merupakan salah satu problem dalam dunia pendidikan di Indonesia saat ini. Dalam proses pembelajaran, anak kurang didorong untuk mengembangkan kemampuan berpikir, mereka cenderung diarahkan untuk menghafal informasi sehingga murid lebih kepada pintar secara teoritis tetapi lemah dalam aplikasi. Melihat realitas inilah perlunya perubahan dalam proses pembelajaran dalam dunia pendidikan saat ini. Maka

${ }^{4}$ England and Associated Companies Throughout the World, Longman Advanced American Dictionary, (London: Pearson Education Limited, 2008), Second Edition, h. 908. 
Hikmatu Ruwaida: Strategi Pembelajaran Fiqih Thaharah di SDN Mundar Kecamatan Lampihong Kabupaten Balangan

dikembangkan pula berbagai strategi-strategi baru yang berguna untuk menunjang tercapainya Standar Kompetensi Lulusan (SKL) yang dikehendaki menurut standar yang telah ditetapkan.

Mata pelajaran agama ditingkat dasar memiliki substansi yang sama, baik itu di sekolah dasar maupun di madrasah, hanya saja di sekolah dasar, mata pelajaran agama dijadikan satu mata pelajaran saja yaitu Pendidikan Agama Islam dan Budi Pekerti, sementara di madrasah menjadi rumpun Pendidikan Agama Islam dibuat dalam mata pelajaran terpisah, terdiri dari Akidah Akhlak, Quran Hadits, Fikih dan Sejarah Kebudayaan Islam.

Pendidikan Agama Islam dan Budi Pekerti dikembangkan dengan tujuan untuk meningkatkan kemampuan siswa dalam hal keimanan dan ketakwaan kepada Tuhan Yang Maha Esa dalam kehidupan sehari-hari. Tujuan pendidikan ini kemudian dirumuskan secara khusus dalam Pendidikan Agama Islam dan Budi Pekerti sebagai berikut.

1. Menumbuhkembangkan aqidah melalui pemberian, pembinaan, dan pengembangan pengetahuan, penghayatan, pengamalan, pembiasaan, serta pengalaman siswa tentang Agama Islam sehingga menjadi muslim yang terus berkembang keimanan dan ketakwaannya kepada Allah SWT; dan

2. Mewujudkan manusia Indonesia yang taat beragama dan berakhlak mulia yaitu manusia yang perpengetahuan, rajin beribadah, cerdas, produktif, jujur, adil, etis, berdisiplin, bertoleransi (tasamuh), menjaga keharmonisan secara personal dan sosial serta mengembangkan budaya agama dalam kehidupan sebagai warga masyarakat, warga negara, dan warga dunia. ${ }^{5}$

Peran guru sangat penting untuk mewujudkan tujuan ini. Guru harus memiliki desain pembelajaran yang tepat agar materi yang disampaikan dapat

\footnotetext{
${ }^{5}$ Kementrian Pendidikan dan Kebudayaan, Silabus Mata Pelajaran Pendidikan Agama Islam dan Budi Pekerti, Jakarta: 2016
} 
Hikmatu Ruwaida: Strategi Pembelajaran Fiqih Thaharah di SDN Mundar Kecamatan Lampihong Kabupaten Balangan

dipahami dan diaktualisasikan oleh peserta didik. Desain ini merujuk kepada penggunaan strategi yang tepat dalam penyampaian materi, agar nilai-nilai Islam dapat dipahami dan dilaksanakan dalam kehidupan sehari-hari.

Pada mata pelajaran PAI di SD, salah satu kompetensi yang diajarkan adalah tata cara bersuci dari hadats kecil dan hadats besar. Materi ini tidak bisa diajarkan hanya dalam tataran teoritis, tetapi harus bisa dipraktekkan oleh peserta didik bahkan nilai thaharah itu juga harus diinternalisasikan pada peserta didik. Strategi pembelajaran merupakan hal penting yang tidak dapat dilepaskan dalam proses pembelajaran karena dengan penggunaan strategi yang tepat akan dapat mempercepat proses pencapaian tujuan pembelajaran. Di tingkat dasar, materi thaharah ini diajarkan di kelas rendah, secara kognitif dan sosial dimana anak masih cencerung sulit untuk fokus pada pembelajaran dan mudah bosan. Dengan strategi yang variatif, peserta didik tidak merasa jenuh dan bosan ketika pembelajaran berlangsung.

Islam menganjurkan untuk selalu menjaga kebersihan jasmani dan rohani. Kebersihan jasmani tercermin dengan bagaimana seseorang selalu bersuci sebelum melakukan ibadah menghadap Allah SWT. Berdasarkan hal tersebut, pada hakikatnya tujuan bersuci adalah agar umat muslim terhindari dari kotoran atau debu sehingga secara sengaja atau tidak sengaja membatalkan ibadah kepada Allah SWT. Namun, banyak umat muslim hanya tahu bahwa bersuci itu sebatas membasuh badan dengan air tanpa mengamalkan rukunrukun bersuci lainnya sesuai syariat Islam. Bersuci atau dalam istilah Islam yaitu "Thaharah" mempunyai makna yang luas tidak hanya berwudhu saja.

Pengertian thaharah adalah mensucikan diri, pakaian, dan tempat sholat dari hadas dan najis menurut syariat Islam. Bersuci dari hadas dan najis adalah syarat syahnya seorang muslim dalam mengerjakan ibadah tertentu.

Oleh karena itu, penulis tertarik untuk melakukan penelitian dengan judul "Strategi Pembelajaran Fiqih Thaharah di SDN Mundar Kecamatan lampihong Kabupaten Balangan". Fokus penelitian ini adalah Strategi 
Hikmatu Ruwaida: Strategi Pembelajaran Fiqih Thaharah di SDN Mundar Kecamatan Lampihong Kabupaten Balangan

pembelajaran yang digunakan dalam pembelajaran Fiqih Thaharah. Manfaat penelitian ini agar guru mengetahui apa dan bagaimana pembelajaran thaharah yang baik bagi anak di lakukan dan dilaksanakan, sekolah mendapatkan formulasi yang tepat tentang pentingnya bersuci bagi anak, orang tua mendapat pemahaman yang benar tentang peran mereka dalam membantu sekolah dalam memberikan pendidikan yang baik bagi anak yang bisa dilakukan di rumah.

Jika ditinjau dari sudut pandang bidang keilmuan, penelitian ini merupakan penelitian kualitatif tentang praktek pendidikan (field research). Penelitian pendidikan merupakan penelitian yang digunakan untuk mendapatkan informasi yang berguna dan dapat dipertanggungjawabkan mengenai proses kependidikan. ${ }^{6}$ Jenis Penelitian ini adalah penelitian kualitatif dengan pendekatan studi kasus. Penelitian kualitatif adalah suatu proses inkuri pemahaman berdasarkan pada tradisi-tradisi metodologis yang jelas tentang inkuisi yang mengeksplorasi masalah sosial atau manusia. Peneliti membangun sebuah gambar kompleks yang holistik, menganalisis kata-kata, melaporkan pandangan-pandangan informan secara detail dan melakukan studi dalam latar alamiah. ${ }^{6}$ penelitian yang dimaksudkan untuk memahami fenomena tentang apa yang dialami oleh subjek penelitian misalnya perilaku, persepsi, tindakan dan lain-lain secara holistik dan dengan cara deskripsi dalam bentuk kata-kata dan bahasa, dalam suatu konteks khusus yang alamiah dan dengan memanfaatkan berbagai metode ilmiah. ${ }^{7}$ Dalam pengumpulan data, peneliti menghimpun data secara empiris. Dari data tersebut dimaksudkan untuk memahami ragam kegiatan yang dikembangkan menjadi suatu pola temuan peneliti, pola temuan tersebut selanjutnya diverifikasikan dengan menguji kebenarannya bertolak pada data baru yang spesifik. Teknik pengumpulan data yang digunakan peneliti 2014), h. 16.

${ }^{6}$ Rulam Ahmadi, Metode Penelitian Kualitatif, (Yogyakarta: Ar-Ruzz Media,

${ }^{7}$ Lexy J. Moeleong, Metode Penelitian Kualitatif, (Bandung: Remaja Rosdakarya, 2005), h. 6. 
Hikmatu Ruwaida: Strategi Pembelajaran Fiqih Thaharah di SDN Mundar Kecamatan Lampihong Kabupaten Balangan

dalam hal ini adalah wawancara, observasi dan dokumentasi. Teknik analisis data dilakukan dengan langkah sebagai berikut.

1. Reduksi data, yakni merangkum, memilih hal-hal yang pokok, memfokuskan pada hal-hal yang penting, dicari tema dan polanya. Dengan demikian data yang telah direduksi akan memberikan gambaran yang lebih jelas dan mempermudah peneliti untuk melakukan pengumpulan data selanjutnya dan mencarinya bila diperlukan.

2. Display data, yakni penyajian data bisa dalam bentuk deskripsi atau uraian singkat, naratif, bagan, hubungan antar kategori, dan sejenisnya sehingga memudahkan untuk memahami apa yang telah terjadi, merencanakan kerja selanjutnya berdasarkan apa yang telah dipahami tersebut.

3. Penyimpulan dan verifikasi, yakni menjawab rumusan masalah yang ada sejak awal yang berupa deskripsi atau gambaran suatu objek yang sebelumnya masih bersifat samar sehingga menjadi jelas, dapat berupa hubungan kausal atau interaktif, hipotesis atau teori. ${ }^{8}$

\section{B. Pembahasan}

\section{Strategi Pembelajaran}

Strategi pembelajaran merupakan rencana tindakan termasuk penggunaan metode dan pemanfaatan berbagai sumber daya dalam pembelajaran. Strategi pembelajaran menentukan pendekatan yang dipilih guru untuk mencapai tujuan pembelajaran. ${ }^{9}$ Strategi pembelajaran juga disebut caracara yang berbeda untuk mencapai hasil pembelajaran yang berbeda di bawah kondisi yang berbeda. ${ }^{10}$ Jadi strategi ini meliputi berbagai tindakan yang

${ }^{8}$ Sugiyono, Metode Penelitian Kuantitatif Kualitatif dan R\&D, (Bandung: Alfabeta, 2012), h. 249-253.

${ }^{9}$ Ridwan Abdullah Sani, Inovasi Pembelajaran, h. 89.

${ }^{10}$ Made Wena, Strategi Pembelajaran Inovatif Kontemporer, (Jakarta: Bumi Aksara, 2014), h.5. 
Hikmatu Ruwaida: Strategi Pembelajaran Fiqih Thaharah di SDN Mundar Kecamatan Lampihong Kabupaten Balangan

dilakukan guru di kelas, mulai dari mengaktifkan peserta didik sampai memberikan umpan balik, yang dikemas untuk mencapai tujuan pembelajaran.

Strategi merupakan rancangan serangkaian kegiatan untuk mencapai tujuan tertentu. Yang diperhatikan dalam dalam menentukan strategi dan metode pembelajaran adalah bahwa strategi dan metode harus dapat mendorong siswa untuk beraktivitas. ${ }^{11}$

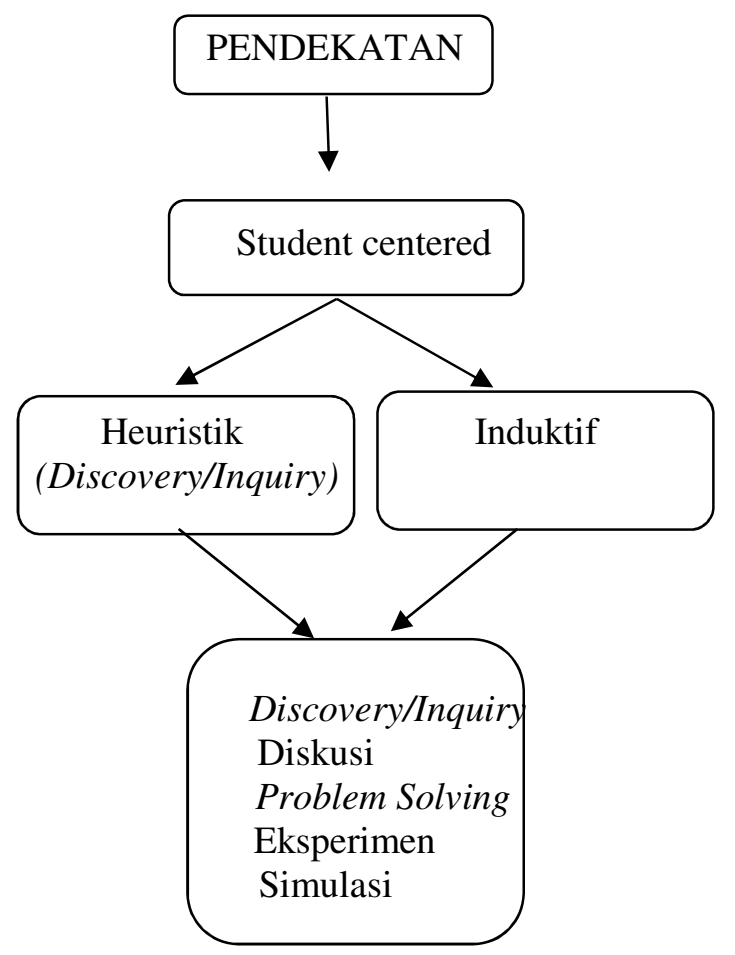

Bagan di atas menunjukkan apabila guru menggunakan pendekatan pembelajaran yang berpusat pada siswa maka strategi yang digunakan adalah heuristik atau induktif dan metode yang digunakan bisa diskusi, simulasi, dan lain-lain yang memungkinkan siswa untuk aktif dalam pembelajaran. ${ }^{12}$

${ }^{11}$ Wina Sanjaya, Perencanaan dan Desain Sistem Pembelajaran, (Kencana, Jakarta: 2011), h. 61.

${ }^{12}$ Masitoh dan Laksmi Dewi, Strategi Pembelajaran, (Departemen Agama Republik Indonesia, Jakarta: 2009), h. 40. 
Hikmatu Ruwaida: Strategi Pembelajaran Fiqih Thaharah di SDN Mundar Kecamatan Lampihong Kabupaten Balangan

Strategi pembelajaran merupakan proses keseluruhan untuk memberdayakan peserta didik, oleh karena itu pembelajaran menggambarkan tiga kategori utama yaitu sebagai berikut.

a. Belajar merupakan proses internal yang terjadi pada individu yang mentransformasi stimulasi dari lingkungan individu ke dalam sejumlah bentuk informasi yang berkembang secara progresif dalam jangka panjang.

b. Kemampuan dan kinerja sebagai hasil belajar yang berorientasi praktis dan teoritis.

c. Peristiwa pembelajaran yang mendukung proses belajar merujuk pada kategori-kategori umum tanpa tergantung dari hasil belajar yang diharapkan. Tujuan pembelajaran yang berhubungan dengan kemampuan intelektual membutuhkan desain dalam peristiwa pembelajaran yang berbeda dengan desain tujuan utnuk kemampuan informasi verbal atau bagi kemampuan motorik. ${ }^{13}$

Jadi, strategi ataupun metode pembelajaran pada kurikulum tidak ditentukan secara khusus, melainkan guru yang memilih dan mengembangkannya, memilih yang dianggap relevan dan efektif untuk tujuan mata pelajaran yang diajarkan maupun pembentukan kompetensi peserta didik, serta memahami dampak yang diperoleh dari penggunaannya.

Beberapa strategi yang dikemukakan oleh Wina Sanjaya sebagai upaya memberikan pengalaman belajar kepada pesera didik adalah sebagai berikut.

a. Strategi pembelajaran ekspositori adalah strategi yang menekankan kepada proses penyampaian materi secara verbal dari seorang guru kepada sekelompok peserta didik dengan maksud agar peserta didik menguasai materi pelajaran secara optimal. Oleh karena strategi ekspositori lebih menekankan kepada proses bertutur, maka sering juga

\footnotetext{
${ }^{13}$ Muhammad Yaumi, Prinsip-prinsip Desain Pembelajaran disesuaikan dengan Kurikulum 2013, (Jakarta: Kencana, 2013), h. 234-235.
} 
Hikmatu Ruwaida: Strategi Pembelajaran Fiqih Thaharah di SDN Mundar Kecamatan Lampihong Kabupaten Balangan

dinamakan dengan istilah strategi chalk and talk dengan fokus utama strategi ini adalah kemampuan akademis. Metode pembelajaran yang sering digunakan adalah metode kuliah atau ceramah. ${ }^{14}$

b. Strategi pembelajaran inkuiri. Inquiry-discovery learning merupakan belajar mencari dan menemukan sendiri. Dalam sistem pembelajaran ini guru menyajikan bahan pelajaran tidak dalam bentuk yang final, tetapi anak didik diberi peluang untuk mencari dan menemukannya sendiri dengan teknik pemecahan masalah. ${ }^{15}$ Strategi pembelajaran inkuiri adalah serangkaian kegiatan pembelajaran yang menekankan pada proses berpikir secara kritis dan analitis untuk mencari dan menemukan sendiri jawaban dari suatu masalah yang dipertanyakan. ${ }^{16}$ Proses berpikir itu sendiri biasanya dilakukan melalui tanya jawab antara guru dan siswa. Strategi pembelajaran ini biasanya sering juga dinamakan strategi heuristic, yang berasal dari bahasa Yunani yaitu heuriskein yang berarti saya menemukan. Tujuan utama pembelajaran melalui strategi inkuiri adalah menolong siswa untuk dapat mengembangkan disiplin intelektual dan ketrampilan berpikir dengan memberikan pertanyaan-pertanyaan dan mendapatkan jawaban atas dasar rasa ingin tahu mereka. Strategi pembelajaran inkuiri merupakan bentuk dari pendekatan pembelajaran yang berorientasi kepada siswa (student centered approach), sebab dalam strategi ini siswa memegang peran yang sangat dominan dalam pembelajaran.

Strategi pembelajaran inkuiri menganggap bahwa siswa merupakan objek dan subjek dalam pembelajaran, mempunyai kemampuankemampuan dasar untuk berkembang secara optimal sesuai dengan

${ }^{14}$ Wina Sanjaya, Perencanaan dan Desain Sistem Pembelajaran, (Jakarta: Kencana, 2011), h. 189.

${ }^{15}$ Syaiful Bahri Djamarah dan Aswan Zain, Strategi Belajar Mengajar, (Jakarta, Rineka Cipta: 1996), h. 22.

${ }^{16}$ Wina Sanjaya, Strategi Pembelajaran Berorientasi Standar Proses Pendidikan, (Jakarta: Kencana, 2008), h. 196. 
Hikmatu Ruwaida: Strategi Pembelajaran Fiqih Thaharah di SDN Mundar Kecamatan Lampihong Kabupaten Balangan

kemampuan yang dimilikinya, serta meletakkan dasar dan mengembangkan cara berpikir ilmiah. ${ }^{17}$

c. Strategi pembelajaran kooperatif menggunakan sistem pengelompokkan atau tim kecil, yang mempunyai latar belakang kemampuan akademis, jenis kelamin, ras atau suku yang berbeda (heterogen). Sistem penilaian terhadap kelompok, setiap kelompok akan mendapat reward jika kelompok mampu menunjukkan prestasi yang dipersyaratkan. Dengan demikian, setiap anggota kelompok akan memiliki ketergantungan positif. Ketergantungan semacam itulah yang selanjutnya akan memunculkan tanggung jawab individu terhadap kelompok dan ketrampilan interpersonal dari setiap anggota kelompok. ${ }^{18}$

\section{Fiqih Thaharah di Sekolah Dasar}

Pendidikan Agama Islam dan Budi Pekerti dikembangkan dengan tujuan untuk meningkatkan kemampuan siswa dalam hal keimanan dan ketakwaan kepada Tuhan Yang Maha Esa dalam kehidupan sehari-hari. Tujuan pendidikan ini kemudian dirumuskan secara khusus dalam Pendidikan Agama Islam dan Budi Pekerti sebagai berikut.

a. Menumbuhkembangkan aqidah melalui pemberian, pembinaan, dan pengembangan pengetahuan, penghayatan, pengamalan, pembiasaan, serta pengalaman siswa tentang Agama Islam sehingga menjadi muslim yang terus berkembang keimanan dan ketakwaannya kepada Allah SWT; dan

b. Mewujudkan manusia Indonesia yang taat beragama dan berakhlak mulia yaitu manusia yang perpengetahuan, rajin beribadah, cerdas, produktif, jujur, adil, etis, berdisiplin, bertoleransi (tasamuh), menjaga keharmonisan secara personal dan sosial serta mengembangkan 2005), h.11-12.

${ }^{17}$ Ahmad Sabri, Strategi Belajar Mengajar, ( Quantum Teaching, Jakarta:

${ }^{18}$ Wina Sanjaya, Perencanaan dan Desain Sistem Pembelajaran, h. 194. 
Hikmatu Ruwaida: Strategi Pembelajaran Fiqih Thaharah di SDN Mundar Kecamatan Lampihong Kabupaten Balangan

budaya agama dalam kehidupan sebagai warga masyarakat, warga negara, dan warga dunia. ${ }^{19}$

Pendidikan atau pembelajaran agama di sekolah pada umumnya dan sekolah dasar khususnya adalah sebagai usaha sadar untuk menyiapkan siswa agar memahami (knowing), terampil melaksanakan (doing), dan mengamalkan (being) agama melalui kegiatan pendidikan atau pembelajaran. Berdasarkan definisi agama ini, maka tujuan pendidikan agama di sekolah ialah anak memahami, terampil, melaksanakan ajaran agama dalam kehidupan sehari-hari sehingga menjadi orang yang beriman dan bertakwa kepada Allah SWT, berakhlak mulia dalam kehidupan pribadi, berkeluarga, bermasyarakat, berbangsa dan bernegara. ${ }^{20}$

Adapun tujuan pendidikan agama Islam untuk tingkat sekolah dasar yaitu :

a. Penanaman rasa agama kepada peserta didik.

b. Menanamkan perasaan cinta kepada Allah dan Rasul-Nya.

c. Memperkenalkan ajaran Islam yang bersifat global, seperti rukun iman dan rukun Islam.

d. Membiasakan anak-anak berakhlak mulia, dan melatih anak-anak untuk mempraktikkan ibadah yang bersifat praktis, seperti shalat dan puasa.

e. Membiasakan contoh teladan yang baik. ${ }^{21}$

Jika merujuk pada kompetensi Pendidikan Agama Islan di sekolah dasar, maka tujuan pembelajaran yang terkait dengan Fiqih adalah memahami tata cara pelaksanaan hukum Islam yang berkaitan dengan ibadah dan muamalah. Lebih spesifik lagi, fiqih thaharah ini diajarkan di tingkat dasar, dengan materi tata cara bersuci. Oleh sebab itu, diperlukan guru yang mampu

\footnotetext{
${ }^{19}$ Kementrian Pendidikan dan Kebudayaan, Silabus Mata Pelajaran Pendidikan Agama Islam dan Budi Pekerti, Jakarta: 2016.

${ }^{20}$ Ahmad Susanto, Teori Belajar Pembelajaran di Sekolah Dasar, (Jakarta: Kencana, 2014), h. 278.

${ }^{21}$ Ahmad Sunanto, Teori Belajar Pembelajaran di Sekolah Dasar, h. 281.
} 
Hikmatu Ruwaida: Strategi Pembelajaran Fiqih Thaharah di SDN Mundar Kecamatan Lampihong Kabupaten Balangan

memilih dan menggunakan strategi yang tepat agar peserta didik memahami, terampil melaksanakannya dalam kehidupan sehari-hari.

Fiqih menurut bahasa "tahu atau paham"22 Firman Allah SWT. :

"... dan hati mereka telah dikunci mati, maka mereka tidak mengetahui" (QS. At-Taubah : 87)

Ada beberapa istilah mengenai Fiqih menurut istilah adalah sebagai berikut:

a. Menurut Abdul Wahhab Khallaf Fiqh adalah "hukum-hukum syara' yang bersifat praktis (amaliah) yang diperoleh dari dalil-dalil yang rinci". 23

b. Menurut A. Syafi'i Karim, fiqih ialah "suatu ilmu yang mempelajari syarat Islam yang bersifat amaliah (perbuatan) yang diperoleh dari dalil-dalil hukum yang terinci dari ilmu tersebut". ${ }^{24}$

c. Menurut Al-Imam Abd Hamid Al-Ghazali, Fiqih adalah ilmu yang menerangkan hukum-hukum syara' bagi para mukallaf seperti wajib, haram, mubah, sunnat, makruh, shahih, dan lain-lain. ${ }^{25}$

Jadi, fiqih ini merupakan kajian amaliah sehari-hari yang disertakan dalil disyariatkannya dan cara melaksanakannya. Dikaitkan dengan pembelajaran, maka pembelajaran fiqih thaharah adalah interaksi pendidik dalam memberikan bimbingan kepada peserta didik untuk mengetahui ketentuan-ketentuan syari'at Islam. Guru membimbing peserta didik agar dapat memahami, menghayati dan mengamalkan pelaksanaan syariat Islam tersebut, yang kemudian terinternalisasi dalam kehidupannya, keluarga dan masyarakat lingkungannya.

${ }^{22}$ Teungku Muhammad Hasbi ash-Shiddieqy, Pengantar Ilmu Fiqh, (Semarang : Pustaka Rizki Putra, 1997), h. 15.

${ }^{23}$ Ahmad Rofiq, Hukum-hukum Islam di Indonesia, (Jakarta : Raja Garfindo Persada, 2000), h. 5.

${ }^{24}$ A. Syafi'i Karim, Fiqih - Ushul Fiqh, (Bandung : Pustaka Setia, 1997), h. 11. 1996), h. 30.

${ }^{25}$ T.M Hasbi Ash-Shidqy, Pengantar Hukum Islam, (Jakarta, Bulan Bintang, 
Hikmatu Ruwaida: Strategi Pembelajaran Fiqih Thaharah di SDN Mundar Kecamatan Lampihong Kabupaten Balangan

Thaharah (طهارة) dalam bahasa Arab bermakna An-Nadhzafah (النظافة), yaitu kebersihan. Thaharah dalam istilah para ahli fiqih adalah :

a. (عبارة عن غسل أعضاء مخصوصة بصفة مخصوصة), yaitu mencuci anggota tubuh tertentu dengan cara tertentu.

b. (رفع الحدث و إزالة النجس), yaitu mengangkat hadats dan menghilangkan najis.

Kata thaharah yang menurut bahasa berarti suci (bersih dari kotoran). Adapun menurut syara' yaitu suatu perbuatan yang karenanya seseorang diperbolehkan mengerjakan sholat, seperti wudhu, mandi, tayammum, dan menghilangkan najis. ${ }^{26}$ Materi fiqih thaharah di sekolah dasar mempelajarai tentang cara bersuci, baik itu bersuci dari hadats dan najis, berwudhu, tayammum dan mandi.

\section{Strategi Pembelajaran Fiqih Thaharah di SDN Mundar Kecamatan lampihong Kabupaten Balangan}

Pembelajaran berarti membelajarkan peserta didik. Maka dalam usaha menerapkan strategi pembelajaran, ada variabel-variabel yang perlu diperhatikan dalam menentukan strategi yang dipakai. Berdasarkan hasil wawancara dengan Ibu Noor Hikmah selaku guru Pendidikan Agama Islam di SDN Mundar, beliau mengatakan bahwa sebelum melaksanakan strategi pembelajaran, maka terlebih dahulu membuat perencanaan tentang apa yang akan dilakukan di kelas. Untuk penentuan strategi, maka perlu diperhatikan karakteristik bidang studi dan kondisi peserta didik. Ibu Noor Hikmah menyatakan, untuk kajian fiqih, materi yang diajarkan lebih banyak tentang perbuatan yang berkaitan dengan ibadah sehari-hari. maka, peserta didik lebih banyak melakukan demonstrasi. Peserta didik di SDN Mundar dikatakan belum memiliki pengetahuan awal, sehingga guru harus mengkondisikan pembelajaran seaktif mungkin. sehingga memerlukan. Strategi pembelajaran yang sering Ibu Noor Hikmah gunakan dalam pembelajaran fikih thaharah adalah demonstrasi

${ }^{26}$ Ahmad Sunarto, Terjemah Fat-Hul Qorib, (Surabaya: Al-Hidayah, tt) h. 20. 
Hikmatu Ruwaida: Strategi Pembelajaran Fiqih Thaharah di SDN Mundar Kecamatan Lampihong Kabupaten Balangan

atau praktek atau simulasi dan ceramah sebelum melakukan praktek. Yang melatarbelakangi pemilihan strategi karena kesulitan siswa dalam memahami pembelajaran apabila hanya dijelaskan saja atau dengan gambar saja ataupun dengan metode yang lainya. Maka dari itu hanya menggunakan metode simulasi dan ceramah saja. karena pembelajaran thaharah ini hanya ada dikelas 1 saja dan pada k-13 ada juga pada kelas 4. Jadi di perlukan contoh atau alat peraga untuk memudahkan pemahaman anak didik. Strategi merupakan rancangan serangkaian kegiatan untuk mencapai tujuan tertentu. Guru mengalami beberapa kesulitan terkait pengajaran materi mandi, terutama hal-hal yang berkaitan dengan penjelasan terkait hal-hal yang menyebabkan mandi. Menurut guru, materi yang disajikan harus menyesuaikan dengan kondisi perkembangan peserta didik. Yang diperhatikan dalam dalam menentukan strategi dan metode pembelajaran adalah bahwa strategi dan metode harus dapat mendorong siswa untuk beraktivitas. Dari keterangan guru PAI di SDN Mundar, diperoleh informasi bahwa strategi penyampaian informasi dari guru kepada peserta didik menggunakan metode ceramah yang diikuti dengan demonstrasi. Kemudian, untuk pemahaman nilai-nilai thaharah, biasanya guru mencontohkan dengan kehidupan sehari-hari dengan harapan anak hidup bersih baik itu di lingkungan sekolah maupun rumah.

Ibu Noor Hikmah meyatakan bahwa problem yang dihadapi dalam pembelajaran thaharah itu yaitu kalau dengan ceramah saja maka sulit mengkondisikan kelas. Kalau dengan metode praktek maka akan memakan waktu yang banyak dan lebih sulit contoh secara nyata karena masih anak-anak. Peserta didik dalam pembelajaran PAI cukup antusias kalau menggunakan media yang disukai oleh anak-anak.

Belajar merupakan proses yang menghendaki perubahan tingkah laku pada diri peserta didik. Oleh karena itu, proses belajar mengajar harus diupayakan mengaktifkan kegiatan fisik maupun psikis peserta didik. Sehubungan dengan hal ini, guru PAI di SDN Mundar menerapkan strategi 
Hikmatu Ruwaida: Strategi Pembelajaran Fiqih Thaharah di SDN Mundar Kecamatan Lampihong Kabupaten Balangan

pembelajaran ekspositori dan inkuiri pada materi fiqih thaharah agar hasil yang didapat bersifat menyeluruh yakni mencakup ranah kognitif, afektif dan psikomotorik. Berdasarkan hasil observasi, peserta didik lebih antusias jika menggunakan pemodelan, tidak ceramah terus menerus.

Keefektifan dan keefisiensian strategi yang digunakan guru dapat dilihat pada hasil pembelajaran. Dalam hal ini kaitannya dengan penguasaan pengetahuan dan ketrampilan yang dipelajari, jumlah waktu yang dipakai peserta didik dalam pembelajaran, dan kecendrungan peserta didik untuk tetap atau terus belajar. Berdasarkan hasil wawancara dan observasi, peserta didik kurang bisa berkonsentrasi jika hanya dengan metode ceramah, oleh sebab itu diperlukan strategi pembelajaran yang variatif agar topik-topik yang dipelajari mampu tersampaikan dan diterima dengan baik oleh peserta didik.

Guru merupakan orang berperan dan bertanggung jawab terhadap perkembangan peserta didik di dalam dan luar kelas baik itu tingkat keberhasilan peserta didik sampai kepada kepribadiannya. Berbagai macam peran dan tanggung jawab tentunya mengharuskan guru harus memiliki kualifikasi pendidikan serta kompetensi-kompetensi yang sesuai dengan konteks profesinya sebagaimana yang telah diatur dalam perundang-undangan sehingga pada saat melaksanakan tugasnya, tujuan pembelajaran dapat dicapai dengan maksimal. Latar belakang pendidikan guru serta berbagai pelatihan keprofesiannya menjadi sangat penting bagi seorang guru PAI. Hal tersebut akan membantu dalam menjalankan tugasnya dalam mengembangkan pembelajaran, dalam hal ini berkaitan juga dengan kemampuan guru dalam menggunakan pendekatan, model, strategi dan metode pembelajaran. Guru PAI di SDN Mundar sebagaimana hasil wawancara berlatar belakang pendidikan S1 Pendidikan Agama Islam STAI RAKHA Amuntai dan sudah mengajar PAI selama 7 tahun. Dalam rangka menambah wawasan dan kualitas keilmuan profesinya, guru juga harus terus mengikuti berbagai pelatihan keprofesian sehingga ia mampu memberikan pembelajaran yang berkualitas kepada peserta 
Hikmatu Ruwaida: Strategi Pembelajaran Fiqih Thaharah di SDN Mundar Kecamatan Lampihong Kabupaten Balangan

didiknya. Guru PAI di SDN Mundar sudah pernah mengikuti beberapa pelatihan pendidikan sehingga sudah mengetahui beberapa strategi dan metode pembelajaran.

Belajar pada dasarnya merupakan proses yang diperoleh dari pengalaman, pengalaman yang bukan hanya diperoleh dari ruang kelas, tetapi juga dari linkungan luar kelas, oleh sebab itu sumber belajar itu tidak tunggal. Dengan menggunakan strategi pembelajaran apapun, guru juga mengkondisikan peserta didik untuk menggunakan media-media lain di luar kelas untuk menunjang tugas-tugas mereka di luar sekolah. Hal ini diharapkan dapat membantu mereka untuk memperoleh pengalaman dari berbagai media baik itu pengalaman langsung maupun tidak langsung. Semakin beragam media yang digunakan guru untuk menunjang pembelajaran, maka semakin mengecil pula kemungkinan peserta didik akan memperoleh pengetahuan yang bersifat verbal.

Alokasi waktu untuk satuan mata pelajaran sangat berpengaruh pada strategi yang digunakan guru di kelas. Jika kegiatan mengaktifkan peserta didik tidak dapat langsung dilaksanakan pada saat jam pelajaran berlangsung, maka guru PAI mengkondisikan untuk tugas luar sekolah agar tujuan pembelajaran dapat dicapai dengan maksimal. Penentuan alokasi waktu juga harus sejalan dengan tingkat kesukaran dan cakupan materi, oleh karena itu pada materi fiqih thaharah, teori-teorinya dekat dengan kehidupan sehingga kegiatan eksplorasi peserta didik di luar jam tatap muka mudah dilaksanakan.

\section{Penutup}

Guru PAI di SDN Mundar menggunakan strategi pembelajaran ekspositori dan inkuiri dalam mengajarkan fiqih thaharah kepada peserta didik. Guru melaksanakan strategi pembelajaran dengan beberapa langkah. Secara umum, langkah-langkah dalam pelaksanaan penerapan strategi pembelajaran yaitu guru memberikan materi secara ringkas, guru meminta peserta didik untuk mengikuti langkah-langkah strategi pembelajaran, guru bersama peserta didik 
Hikmatu Ruwaida: Strategi Pembelajaran Fiqih Thaharah di SDN Mundar Kecamatan Lampihong Kabupaten Balangan

melakukan klarifikasi, kesimpulan dan tindak lanjut berupa evaluasi pembelajaran. Dalam penelitian ini juga ditemukan bahwa penggunaan strategi maupun metode pada dasarnya memiliki latar belakang tertentu, seperti kompleksitas tujuan pembelajaran, nilai efektivitas dan efisiensi dan kesesuaian dengan kondisi serta karakteristik peserta didik.

Adapun yang mempengaruhi penerapan strategi tersebut adalah kemampuan guru, kondisi peserta didik, dan alokasi waktu. Alokasi waktu untuk satuan mata pelajaran sangat berpengaruh pada strategi yang digunakan guru di kelas. Jika kegiatan mengaktifkan peserta didik tidak dapat langsung dilaksanakan pada saat jam pelajaran berlangsung, maka guru PAI mengkondisikan untuk tugas luar sekolah agar tujuan pembelajaran dapat dicapai dengan maksimal. Penentuan alokasi waktu juga harus sejalan dengan tingkat kesukaran dan cakupan materi, oleh karena itu pada materi fiqih thaharah, teori-teorinya dekat dengan kehidupan sehingga kegiatan eksplorasi peserta didik di luar jam tatap muka mudah dilaksanakan. 
Hikmatu Ruwaida: Strategi Pembelajaran Fiqih Thaharah di SDN Mundar Kecamatan Lampihong Kabupaten Balangan

\section{Daftar Pustaka}

Abdullah Sani, Ridwan. Inovasi Pembelajaran. Jakarta: Bumi Aksara, 2014.

Ahmadi, Rulam. Metode Penelitian Kualitatif. Yogyakarta: Ar-Ruzz Media, 2014.

Bahri Djamarah, Syaiful, Aswan Zain. Strategi Belajar Mengajar. Jakarta, Rineka Cipta: 1996.

England and Associated Companies Throughout the World, Longman Advanced American Dictionary. London: Pearson Education Limited, 2008.

Hasbi Ash-Shidqy, T.M. Pengantar Hukum Islam. Jakarta: Bulan Bintang, 1996.

J. Moeleong, Lexy. Metode Penelitian Kualitatif. Bandung: Remaja Rosdakarya, 2005.

Kementrian Pendidikan dan Kebudayaan, Silabus Mata Pelajaran Pendidikan Agama Islam dan Budi Pekerti, Jakarta: 2016.

Masitoh, Laksmi Dewi. Strategi Pembelajaran. Departemen Agama Republik Indonesia, Jakarta: 2009.

Muhammad Hasbi ash-Shiddieqy, Teungku. Pengantar Ilmu Fiqh. Semarang: Pustaka Rizki Putra, 1997.

Rofiq, Ahmad. Hukum-hukum Islam di Indonesia. Jakarta: Raja Garfindo Persada, 2000.

Sabri, Ahmad. Strategi Belajar Mengajar. Jakarta: Quantum Teaching, 2005.

Sagala, Syaiful. Konsep dan Makna Pembelajaran. Bandung: Alfabeta, 2006.

Sanjaya, Wina. Perencanaan dan Desain Sistem Pembelajaran. Jakarta: Kencana, 2011.

Perencanaan dan Desain Sistem Pembelajaran. Kencana, Jakarta: 2011.

Al-Madrasah: Jurnal Ilmiah Pendidikan Madrasah Ibtidaiyah

Vol. 3, No. 2, Januari-Juni 2019 
Hikmatu Ruwaida: Strategi Pembelajaran Fiqih Thaharah di SDN Mundar Kecamatan Lampihong Kabupaten Balangan

Strategi Pembelajaran Berorientasi Standar Proses Pendidikan. Kencana, Jakarta: 2008.

Sugiyono. Metode Penelitian Kuantitatif Kualitatif dan R\&D. Bandung: Alfabeta, 2012.

Sunarto, Ahmad. Terjemah Fat-Hul Qorib. Surabaya: Al-Hidayah, tt.

Teori Belajar Pembelajaran di Sekolah Dasar. Jakarta: Kencana, 2014.

Syafi'i Karim, A. Fiqih - Ushul Fiqh. Bandung : Pustaka Setia, 1997.

Undang-undang Republik Indonesia Nomor 20 Tahun 2003 Tentang SISDIKNAS dan Peraturan Pemerintah Republik Indonesia Tahun 2010 Tentang Penyelenggaraan Pendidikan Serta Wajib Belajar. Bandung: Citra Umbara, 2010.

Wena, Made. Strategi Pembelajaran Inovatif Kontemporer. Jakarta: Bumi Aksara, 2014.

Yaumi, Muhammad. Prinsip-prinsip Desain Pembelajaran disesuaikan dengan Kurikulum 2013. Jakarta: Kencana, 2013. 
Hikmatu Ruwaida: Strategi Pembelajaran Fiqih Thaharah di SDN Mundar Kecamatan Lampihong Kabupaten Balangan

Al-Madrasah: Jurnal Ilmiah Pendidikan Madrasah Ibtidaiyah Vol. 3, No. 2, Januari-Juni 2019 